\title{
Constructivist Approach in Learning Chemistry : A Case of High School in Nepal
}

\author{
Rishi Ram Subedi \\ subedirishiram258@gmail.com \\ Central Department of Education, T.U., Kirtipur
}

\begin{abstract}
This study examined the effectiveness of constructivist approach on learning in chemistry by using pre-test, post-test, and experimental and control group design. A sample of 32, grouped as experimental group (16) and control group (16) ongrade XII students of Laboratory secondary school were selected by using the random sampling technique. 5E's learning (Engage-Explore-Explain-Elaborate-Evaluate) strategy has been applied to experimental group and Traditional method of teaching followed by control group. Pre and post tests were used to see the difference in two groups. T-test was used to check the significance difference between experiment and control group after experiment. The result shows that Constructivist learning approach significantly improves student's achievement in chemistry as compared to using a traditional teaching. It is therefore recommended that constructivist 5E-model strategy be used in teaching for the development of student's higher achievement in chemistry at secondary level.
\end{abstract}

Keywords : Academic achievement, Constructivist and traditional teaching method, Effectiveness, 5E-model.

\section{Introduction}

The main aims of this research isto find out the effectiveness of the conventional methods over constructivist approach. Constructivist teaching is based on constructivist learning theories and model given by the work of Dewey, Montessori, Piaget, Brunner and Vygotsky among others provides historical precedents for constructivist learning theory. Formalization of the theory of constructivism is generally attributed to Jean Piaget, who articulated mechanism as that by which knowledge is internalized by the learners (Mohan, 2010). He suggested that through process of 'accommodation' and 'assimilation', individuals construct new knowledge from their experiences. The Biological Science Curriculum Study (BSCS) developed 5Es instructional model of constructivism, which was recommended for science teaching. In this model, the process is explained by employing 5E's. They are Engage-Explore-Explain-Elaborate-Evaluate (BSCS \& IBM, 1989).

The origins of constructivism of one strand is Piaget's genetic epistemology and his central concern was with the process by which humans construct their knowledge of the world (Piaget, 
1973). The other strand of learning theory has its origins in Vygotskian social constructivist perspective recognizes that learning involves being introduced to a specific cultural community (Bruner 1985). According to this perspective, the world is a symbolic world in the sense that it consists of conceptually organized, rule bound belief systems about what exists, about how to get to goals, about what is to be valued. There is no way, none, in which a human being could possibly master that world without the aid and assistance of others for, in fact, that world is others (Bruner, 1985). In this perspective knowledge are constructed when individuals engage socially in talk and activity about shared problems and tasks.

Constructivism is a learning theory in which learning occurs in active process and constructs new idea based on their past and current knowledge (Taylor, 1993). So, it cannot be directly transmitted but must be actively constructed by learners. It is based on the knowledge is not a thing that can be simply given by the teacher inside the classroom to the students at their desks. So, the role of teacher in the classroom is to act as a 'guide on the side' (Brooks, \& Brooks, 1993). Instruction is only process of supporting that construction rather than communication of knowledge. Therefore, the teacher's job is to provide opportunities for learners to expand their knowledge in an active and engaged format (Wilson \&Cole, 1991). According to Richardson (1977), individuals create or construct their own new understanding or knowledge through the interactions on what they already know and believe and ideas, events and activities with which they come in contact. Constructivist teaching asks a question to the students, who then work together in small groups and discover one or more solutions (Yager, 1991). Students are more active for doing experiments and reaching their own conclusions. Teachers act as a facilitator for the students in developing new insights and connecting them with previous knowledge, but leave the discovery and discussion to the student groups (Nayak, 2012).

But, in the conventional method, classes are usually dominated by teacher. Students are only accepter the information they are given without questioning the instructor (Steffe \& Gale, 1998). The teacher seeks to transfer thoughts and meanings to the passive student leaving little room for student-initiated questions, independent thought or interaction between students (Zhang, 1998). This teacher-centered method of teaching also assumes that all students have the same level of background knowledge in the subject matter and are able to absorb the material at the same pace (Lord, 1999).

Traditional teaching approach (lecture method) is very common in education especially in the context of Nepal at secondary level. Traditional method involves coverage of the context and rote memorization on the part of the students and it does not involve students in creative thinking and participation. The up-and-coming trends changed the present scenario and adopted the constructivist approach which is more scientific and more focus on innovative activities and knowledge construction. So, in secondary level, chemistry knowledge construction is very essential and welcomes constructivist approach (5E-model) of teaching. Matthews (2002) have reported that science students independently perceived their classroom environment in a more favorable light than students of other stream. Kim (2005) have found that constructivist teaching is more efficient than traditional; also, ineffective in relation to self-concept and learning strategy but has some effect on motivation anxiety towards learning and self-monitoring. Adak (2017) 
reported that low achiever students that learnt through constructivist approach had achieved significantly higher score as compared to their counterpart that learnt by traditional method for science subject.

Based on this, the researcher wants to find out the extent of significant effect constructivist approach has on student achievement in comparison to traditional method; hence it is worthwhile to study the effect of constructivist approach on the achievement of chemistry students. An analysis of all the above studies indicates that the application of constructivist approach during the teaching of chemistry has been widely used.

\section{Objectives of the study}

- To compare the student's achievement in chemistry teach by the constructivist method after the treatment.

- To find out the effectiveness of constructivist and conventional teaching method in relation to academic achievement of class XII students in chemistry.

\section{Hypothesis of the study}

Null Hypothesis (Ho): There is no significant difference between mean achievement scores of experimental and control groups.

Alternative Hypothesis (H1): There is significant difference between mean achievement scores of experimental and control groups.

\section{Materials and Methods}

Design: This study is based on experimental design. The researcher was constructed two group i.e experimental group and controlled group. Out of these two groups experimental group was taught by instructional module and another control group taught by conventional method. Therefore pre-test, post-test equivalent group design was adopted for the purpose of this study.

Table 1. Design of the Study

$\begin{array}{cccc}\text { Group } & \text { Pre-test } & \text { Treatment } & \text { Post-test } \\ \text { Experimental }\left(\mathrm{E}_{\mathrm{R}}\right) & \mathrm{T}_{1} & \mathrm{X} & \mathrm{T}_{2} \\ \text { Control }\left(\mathrm{C}_{\mathrm{R}}\right) & \mathrm{T}_{1} & \neq & \mathrm{T}_{2}\end{array}$

Where,ER=Randomized experimental group, $\mathrm{CR}=$ Randomized control group, $\mathrm{T} 1=$ Pre-test for experimental and control group, T2=Post-test for experimental group and control group, $\mathrm{X}=$ Treatment with instructional module and $\neq=$ Treatment with conventional method.

Sample: The sample of the present study was confined to 32 students of grade XII by using random sampling method from Laboratory school Kathmandu district in Kritipur municipality.

Tools used: Achievement Test of chemistry subject for grade XII developed by the researcher himself was used in the present study. 
Statistical techniques: In the present study mean, standard deviation, variance and t-test was used to analyses the data computed by SPSS software.

\section{Result}

Pre and post Tests was administered to both experimental and control groups. Test results were entered to SPSS. After pre-test, t-test was used to check difference between both groups. After post-test, t-test was used to find the effectiveness of either constructivist or conventional method of teaching.

Table 2. Analysis of Pre-test Scores Obtained by the Students Taught by control and Experimental group

\begin{tabular}{|c|c|c|c|c|c|c|c|c|}
\hline $\begin{array}{l}\text { Group } \\
\text { size }\end{array}$ & $\begin{array}{r}\text { S } \\
\text { Mean }\end{array}$ & $\begin{array}{l}\text { ample } \\
\text { Deviation }\end{array}$ & Variance & & $\begin{array}{l}\text { t- value } \\
\text { (two- tail) }\end{array}$ & Sig. & $\mathrm{df}$ & Remarks \\
\hline Control & 16 & 26.75 & 3.39 & 11.53 & 0.67 & 0.94 & 15 & $0.94>0.05$ \\
\hline Experin & nental & 16 & 26.69 & 2.30 & 5.29 & & & \\
\hline
\end{tabular}

Table 2 shows that the mean scores of the pre-test of traditional and constructivist method in chemistry were 26.75 and 26.69 respectively. The calculated standard deviation found to be 3.39 and 2.30 and variance 11.5 and 5.29 for control and experimental group respectively. The calculated t-value was found to be $0.67, p=0.94>0.05$ for both group. Since the calculated $p$ value is greater than the standard p- value 0.05 , thus the null hypothesis was accepted. It indicates that there is no significant difference in achievement score of chemistry and both groups are equivalent and homogeneous before treatment. It means constructivist method is better than comparison to conventional methods.

Table 3. Analysis of Post-test Scores Obtained by the Students Taught by Traditional and constructivist-based Teaching

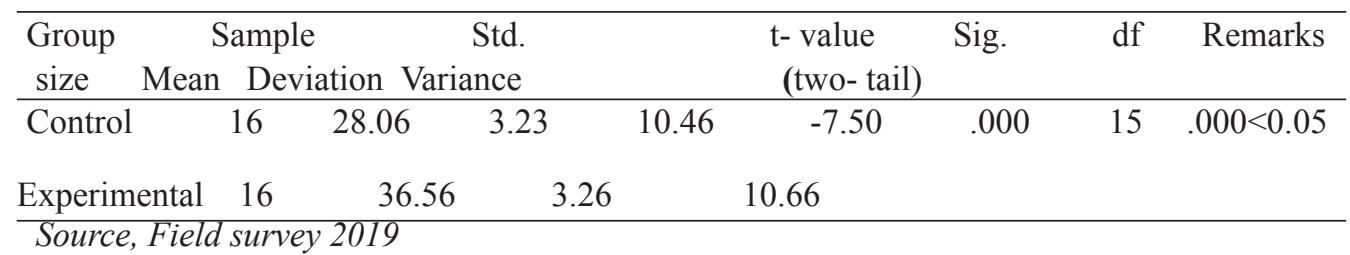

Table 3 flashes that the mean scores of the post-test of traditional and constructivist method in chemistry were 28.06 and 36.56 respectively. The calculated standard deviation found to be 3.23 and 3.26 and variance 10.46 and 10.66 for control and experimental groups respectively. The calculated t-value was found to be $-7.50, p=.000<0.05$ for both group. Since the calculated $\mathrm{p}$ - value was less than the standard p- value 0.05 , thus the null hypothesis was rejected, and alternative hypothesis was accepted. It indicates that the post -test achievement score in science between traditional and constructivist group students after treatment is significantly different. 
Therefore, this study indicated that the achievement score of students taught by constructivist method was better than traditional method.

Table 4. Comparison between Pre-test and Post-test Scores Obtained by the Students Taught by Traditional teaching

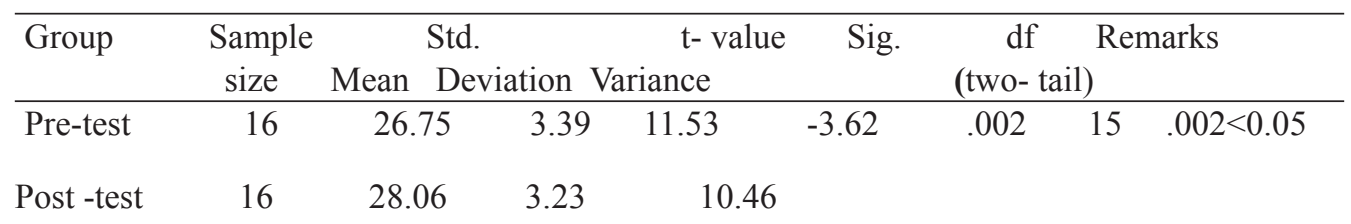

Source, Field survey 2019

Table 4 shows that the mean scores of the pre -test and post-test of traditional group student in chemistry were 26.75 and 28.06 respectively. The calculated standard deviation were found to be 3.39 and 3.23 and variance 11.53 and 10.46 for pre-test and post-test respectively. The calculated $\mathrm{t}$-value was found to be $-3.62, \mathrm{p}=0.02<0.05$ for both test. Since the calculated $\mathrm{p}$ - value is less than the standard p-value 0.05 , thus null hypothesis was rejected, and alternative hypothesis was accepted. It indicates that there was significance difference between two mean scores on pretest and post -test. Thus, it is concluded that the post- test achievement of traditional group was significantly better than the pre-test.

Table 5. Comparison between Pre-test and Post-test Scores Obtained by the Students Taught by constructivist method of teaching

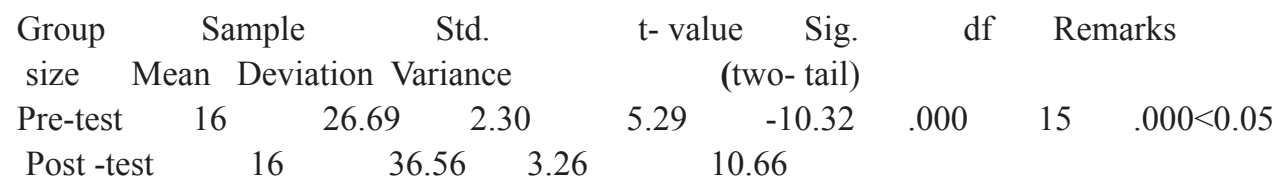

Source, Field survey 2019

Table 5 shows that the mean scores of the pre -test and post-test of constructivist group student in chemistry were 26.69 and 36.56 respectively. The calculated standard deviation 2.30 and 3.26 and variance were found to be 5.29 and 10.66 for pre-test and post-test respectively. The calculated $\mathrm{t}$-value was found to be $-10.32, \mathrm{p}=.000<0.05$ for both test. Since the calculated $\mathrm{p}$ - value is less than the standard p-value 0.05 , thus null hypothesis was rejected, and alternative hypothesis was accepted. It indicates that there was significance difference between two mean scores on pre-test and post -test. So, it is concluded that the post- test achievement of constructivist- based group was significantly better than the pre-test. Thus, the use of constructivist method in chemistry teaching is more effective than comparison to traditional teaching method. 
Comparison of Control and Experimental Group in the Achievement Test of chemistry.

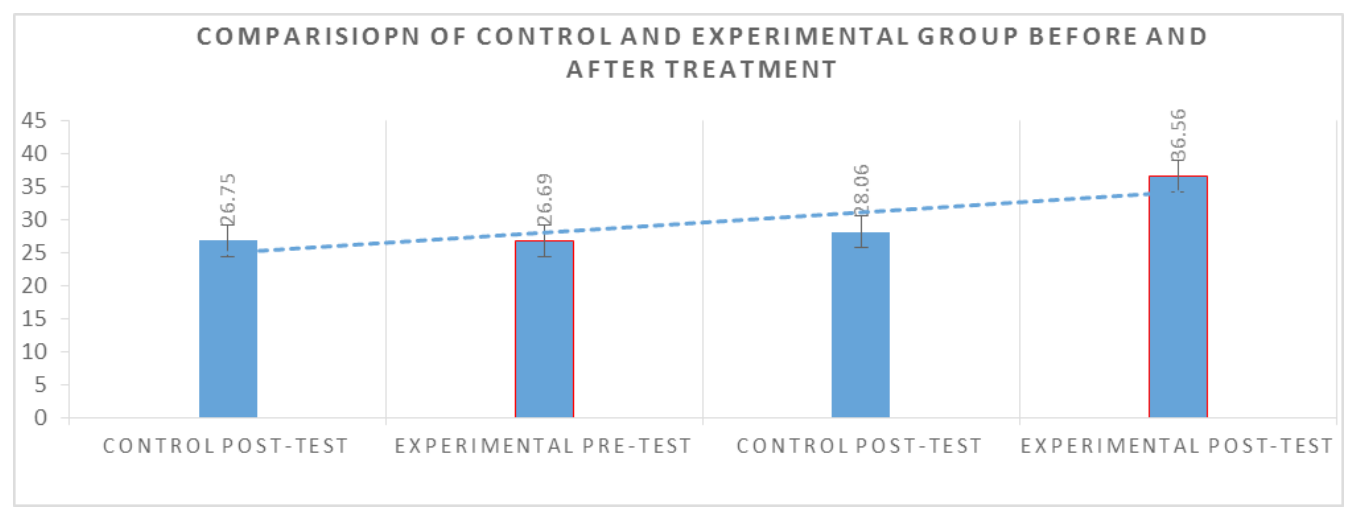

Figure 1. Comparison of Control Group and Experimental Group in the Achievement Test of Chemistry

In above figure clearly shows that two groups of students were equal in their academic achievement before the treatment and after the treatment control group significantly perform poor than the experimental group. It find that treatment has a positive effect on the students' achievement in chemistry. Therefore, constructivist teaching method is significantly better than the traditional method of teaching in the achievement of grade XII students in Chemistry.

\section{Finding and Discussion}

From the studies it was found that Constructivism based teaching significantly improved academic achievement in comparison to traditional method of teaching of class XII chemistry students. The Constructivist Approach has a positive effect on the achievement of students in chemistry. It is evident from the analysis that the students taught by constructivist approach scored higher than those taught by conventional method in the control group. This finding is supported by the findings of a number of studies. The constructivist teaching method is found to be significantly more fruitful in the formation of concept among the math students as compared to traditional method of teaching (Chowdhury, 2015). Kim (2005) found that using constructivist teaching methods of 6th grades resulted in better student achievement than traditional methods. Bhattacharya (2015) also found that teachers who were using constructivism in teaching in class, achievements of their students increased.

The main advantage of the constructivist instruction was that the students derived the scientific facts after long discussions with their peers; scientific facts were not narrated by the teacher as in the traditional instruction (Hanuscin \& Lee 2008). Since students cannot discover all important ideas on their own, social interaction is a vital part of their educational excursion. Students benefit from discussions with teachers and interactions with peers who can help them to acquire new concepts. Further, students received information that has been organized by others, so long as it is meaningful to their way of thinking and knowing. In this way, the teacher also created a learning environment where students could use their prior knowledge and become aware of their already existing conceptions. Wheately (1991) believed that one way to make sense of how students learn is through constructivism. During discussion with their peers, the students tried 
to make a connection between their existing knowledge and the new concept. They analyzed, interpreted, and predicted information. By this way they constructed knowledge actively, instead of receive it from the teacher passively. Teaching and learning was an interactive process that engaged the learners in constructing knowledge. Learning is regarded as an active process whereby students construct personal meaning of the subject matter through their interactions with the physical and social world (Brooks \& Brooks, 1993).

The learning process is facilitated by the skilled teacher who engages students in thinking, questioning, testing ideas, explaining, and representing ideas. So, finding suggested that the experimental group in this study were provided for meaningful learning to be occur. After the results are assessed, it is seen that there is a significant mean difference between the experimental and control group. Both groups of students increased their understanding in the chemistry concept as expected, but the improvement is greater in the experimental group.

\section{Educational implication}

The present study was investigating the effectiveness of constructivist method in teaching science as compared to conventional method. The experimental approach was developed by the researcher keeping in mind the basic and application of constructivist method. Special care was taken with reference to the planning, implementing and controlling of the experiment. This study leads to the educational aims towards the higher academic pursuit in developing science process skills, scientific temper, attitudes, understanding as well as critical thinking abilities to give rise to higher academic achievement as it was specifically developed for the purpose. Besides this, this study can be applied on trainee teachers or teacher trainers and teaching performance can be checked.

\section{Conclusion}

From the result and discussion of the study, the mean achievement score of the students learnt by constructivist method was significantly greater than the students taught by traditional method. It indicates that the constructivist method provides better understanding which enhance the student's achievement in chemistry at class XII, because constructivist method encourages students learning at his/her own pace according to their interest. Different types of practical examples, experiments and cooperative activities made the constructivist method of teaching effective and interesting to the students. So, this paper concluded that constructivist teaching method is more effective and fruitful in teaching Chemistry than the conventional method of teaching.

\section{References}

Adak. S. (2017). Effectiveness of constructivist approach on academic achievement in science at secondary level. Educational Research and Review, 12(22); 1074-1079. Retrieved from: http://www.academicjournals.org/ERR

Bhattacharya, P.D. (2015). Effectiveness of constructivist teaching method: An experimental study. Journal of Research in Social Sciences and Humanities, 5 (1), 2249-4642. Retrieved from: http://www.ijrssh.com

Brooks, M.G. \& Brooks J.G. (1993). The courage to be constructivist. Educational Leadership. November, 18-24. 
Bruner, J. (1985). Vygotsky: A Historical and Conceptual Perspective in J. Wertsch (ed.), Culture, Communication and Cognition: Vygotskian Perspectives, Cambridge University Press, England, pp. 21-34.

BSCS \& IBM. (1989). New Designs for Elementary Science and Health: A Cooperative Project between Biological Sciences Curriculum Study (BSCS) and International Business Machines (IBM). Dubuque, IA: Kendall/Hunt Publishing Company.

Chowdhury, R.C. (2015). A study on the effect of constructivist approach on the achievement in mathematics of IX standard students. Journal of Humanities and Social Science, 21(2); 35-44. Retrieved from: www.josrjornal.org

Hanuscin, D., \& Lee, M. H. (2008). Using the learning cycle as a model for teaching the learning cycle to preservice elementary teachers. Journal of Elementary Science Education, 20(2), 51-66.

Kim, j. (2005). The Effects of a Constructivist Teaching Approach on Student Academic Achievement, Self-Concept, and Learning Strategies. Asia Pacific Education Review 6 (1): 7-19 Retrieved from: http://eric.ed.gov/ERICDocs/data/ericdocs2sq1/content_ storage_01/0000019b/80/2a/5a/af.pdf.

Lord, T.R. (1999). A comparison between traditional and constructivist teaching in environmental science. Journal of Environmental Education. 30(3), 22-27.

Matthews, M.R. (2002). Constructivism and science education: A further appraisal. Journal of Science Education and Technology 11 (2), 121-134. Retrieved from: http://www.jstor. org/stable/40188717

Mohan, R. (2010). Innovative science teaching. New Delhi: PHI Learning Private Limited.

Nayak, R.K. (2012). A study on Effect of Constructivist Pedagogy on Students' Achievement in Mathmatics at Elementary Level. A research article of Nation Institute of Open Schooling (NIOS). India

Piaget, J. (1973). To understand is to Invent: The Future of Education. New York: Grossman Publishers.

Richardson, V. (1997). Constructivist teaching and teacher education: Theory and practice. In V. Richardson (Ed.), Constructivist teacher education: Building new understandings (pp. 23-35). London: Falmer.

Steffe, P. L. and Gale, J. (1995). Constructivism in Education. New Jersey: Lawrence Erlbaum Associates, Inc.

Taylor, P.C. (1993). The influence of researcher on constructivist teaching practice in K. Tobu (ED.), The Practice of Constructivism in Science and Mathematics Education. NJ: Lawrence Erlbaum.

Wheatley, G.H. (1991). Constructivist perspectives on science and mathematics learning. Science Education, 75(1), 9-21.

Wilson, B. \& Cole, P. (19991). A review of cognitive teaching modules. Educational Technology Research and Development, 39(4), 47-64.

Yager, R.E. (1991). The constructivist learning model towards real reform in science education. Science Teacher, 58, 52-57.

Zhang, C. (2001). An investigation of traditional and constructivist models for internet training and attitude of pre-service teachers. Ph.D., University of Toledo, DAI 30330859. 